\title{
Lexical Enrichment in English and Kurdish: A Comparative Study
}

\author{
Khalid Ali Abdullah ${ }^{1} \&$ Soran Abdulrahman Hemed ${ }^{2}$ \\ ${ }^{1}$ College of Education-English Department, University of Raparin, Ranya, Iraqi-Kurdistan \\ ${ }^{2}$ College of Basic Education-Kurdish Department, University of Raparin, Ranya, Iraqi-Kurdistan \\ Correspondence: Khalid Ali Abdullah, College of Education-English Department, University of Raparin, Ranya, \\ Iraqi-Kurdistan. E-mail: bozhin@uor.edu.krd
}

Received: December 3, 2019 Accepted: January 2, 2020 Online Published: February 5, 2020

doi:10.5539/ijel.v10n2p159 URL: https://doi.org/10.5539/ijel.v10n2p159

\begin{abstract}
The present study is a comparative study of lexical enrichment between English and Kurdish. It aims to compare the methods and the processes by which new words are formed and/ or new lexical items come to the languages. It explains how both languages can be enriched and which method or process is more common and productive than others in the two languages. The study consists of two sections. The first section is about the ways and the methods of lexical enrichment in English. The second section is about lexical enrichment in Kurdish in which similarities and differences are explained between the two languages. At the end of the study there are some important conclusions taken from the research, a list of Kurdish phonemic symbols and a list of English and Kurdish references.
\end{abstract}

Keywords: lexical enrichment, word formation, affixation, loan words, shortening, English and Kurdish

\section{Introduction}

English is a universal language so it has a great influence on other languages all over the world. Among all the languages in the world, Kurdish is one of those that has been influenced by other languages (especially by English) and has borrowed words from them to enrich its lexical items. English, like other languages, has its own way of enriching its lexical items. The following ways are the most common ones by which new lexical items entered the English language.

\section{Lexical Enrichment in English}

English, as a universal language, has some ways to enrich the language. The following ways are the most important ones:

\subsection{Lexical Enrichment in English by Word-Formation}

In English, there are many ways to form new words, but some of the ways are more common and more productive than others. The following ways are the most important when it comes to word-formation in English:

\subsubsection{Affixation}

Affixation, in English, is the most common way of word-formation by which a new lexical item can come to the language from an old lexical item by adding derivational affixes to open classed words. In general, in English, words are formed by two kinds of affixes which are known as prefix and suffix (Leiber, 2012, p. 33, 35). This does not mean that there are no infixes in English. English has infixes, but they are a rarity.

\subsubsection{Prefixes}

Prefixes are those kinds of affixes that are attached to the beginning of the root, stem or the base of the word and the class of the word is not changed. For example:

- $\quad$ Re + write $=$ rewrite

- $\quad$ Un + kind $=$ unkind

- $\quad$ In + accurate $=$ inaccurate

\subsubsection{Suffixes}

Suffixes are those kinds of affixes that are attached to the end of the root, stem or the base of the word and the 
class of the word may or may not be changed, but a new form with a new meaning is made. For example:

- $\quad$ Kind + ly $=$ kindly

- $\quad$ Drive + er $=$ driver

- Help + ful $=$ helpful (Katamba \& Stoneham, 2006, pp. 44-45)

\subsubsection{Conversion}

This process is known as zero-affixation because in this process a new lexeme is produced from the old lexeme without any affix. Here, only the function and the class of the word is changed. In English, mostly, a new verb is produced from a noun by conversion. For example:

\begin{tabular}{|c|c|}
\hline Noun & $\underline{\text { Verb }}$ \\
\hline - Table & to table \\
\hline Bread & to bread \\
\hline Fish & to fish \\
\hline Test & to test \\
\hline Face & to fish \\
\hline
\end{tabular}

Also, it is possible to form nouns from verbs, as the opposite of the above examples:

$\begin{array}{lll} & \text { Verb } & \text { Noun } \\ \text { - } & \text { To throw } & \text { throw } \\ - & \text { To kick } & \text { kick } \\ - & \text { To fix } & \text { fix }\end{array}$

Moreover, it is possible to form verbs from adjectives but they are less common than the others:
Adjective
$\underline{\text { Verb }}$
- Cool
to cool
- Yellow
to yellow

When new verbs are formed from nouns, the resulting verbs, sometimes, have a wide range of meanings. For instance, to bread means 'to put bread on something', but to fish means 'to take fish from a body of water'. And to clown means 'to act like a clown' rather than to put a clown somewhere or take a clown from somewhere! On the other hand, when a noun is converted into a verb, the meaning of the new word is usually more predictable. The result usually means something like 'an instance of $\mathrm{X}$-ing', where $\mathrm{X}$ is the denotation of the verb. For instance, a throw is 'an instance of throwing'.

Morphologists have different views on how to analyze conversion. Some state that this process is just like the process of affixation, but the added affix is phonologically null that is not pronounced.

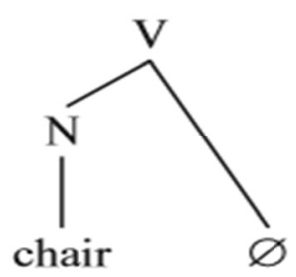

In contrast, other morphologists state that conversion is different from affixation, and treat it as a change of category without any accompanying change of form. For instance, the converted verb, like 'to chair', does not have any internal structure, but is regarded as having been relisted or recategorized in the mental lexicons of humans. (Lieber, 2012, pp. 49-50)

Sometimes, in the process of conversion, a new lexeme is created by changing the place of the stress in the word. For instance:

$$
\begin{array}{ll}
\underline{\text { Verbs }} & \underline{\text { Nouns }} \\
\text { transfér } & \text { tránsfer }
\end{array}
$$




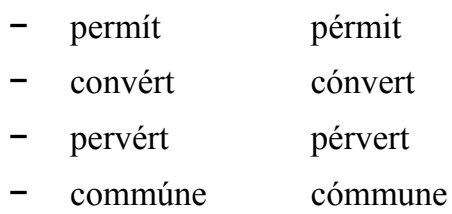

Moreover, in the process of conversion, both words often become established, and then it is not clear which word came first without looking them up in a dictionary. For instance, the noun electronic mail, became e-mail, and almost at once became a verb as well:

- She e-mailed me about the meeting (Denham \& Lobeck, 2013, p. 200).

\subsubsection{Coinage}

Coinage is the least common way by which a new lexeme is created in English as a result of new inventions, events and trading. The most typical sources are invented trade names for commercial products that become general terms for any version of that product.

- aspirin

- nylon

- vaseline

- teflon

- Kleenex

- hoover

Some of the new words refer to the person who invented something, or to the place where something was invented. These new words are known as eponyms in English. For instance:

- sandwich

The word 'sandwich' derived from a name (the Earl of Sandwich) who first insisted on having his bread and meat together while gambling.

- jeans

The word 'jeans' derived from the Italian city of Genoa where this type of cloth was first made.

Some eponyms are technical terms, based on the names of those who first discovered or invented things, for example:

- fahrenheit (from the German, Gabriel Fahrenheit)

- volt (from the Italian, Alessandro Volt)

- watt (from the Scottish inventor, James Watt)

These terms are written without a capital letter (Yule, 2010, pp. 53-54).

\subsubsection{Retronyms}

Retronym is another way of word formation that supplies a new name for something to differentiate the original word from a more recent form or version. The original word becomes a modifier, rather than being completely replaced by a new word, to account for developments of the object or concept:

The original word the new word

- Analog watch digital watch

- Acoustic guitar electric guitar (Denham \& Lobeck, 2013, p. 199)

\subsubsection{Compounding}

2.1.5.1 Compounding by the combination of two words or bases

Compounding is one of the processes of word formation in which two independent words or bases are combined and a new single independent word is formed. For instance, the word 'football' is formed by the combination of the words 'foot' and 'ball' (Yule, 2010, p. 54).

Compound words can be produced in other ways, for instance:

- Free root $($ motor $)+$ free root $($ bike $)=$ motorbike 
- Bound root (micro) + bound root (scopy) = microscopy

- Bound root (micro) + free root (film) $=$ microfilm

\subsubsection{Compounding by Reduplication}

In this process, a part of the base of the word or the whole base is copied and linked to the beginning or the end of the base of the same word to form a compound word. If the whole base is repeated, the process will be called 'total reduplication'.

- Willy-nilly

- Wishy-washy

- Hush-hush

- Blah-blah

- $\quad$ pooh-pooh (Haspelmath \& Sims, 2010, p. 39; Booij, 2007, pp. 35-36)

\subsubsection{Shortening}

Another means of word formation in English is known as shortening. In the process of shortening, words are deliberately shortened for economical purposes, such as to save the time and effort of saying the words. There are different ways of shortening words:

\subsubsection{Taking the initial letters of a set words}

\subsection{Word acronym}

A word acronym is formed by shortening a group of words into a single word. The initial letters of a set of words are taken and these letters are linked together to form a new single word form (word acronym). The word acronym is treated as an independent word and pronounced as a single word; it gives the meaning of the set of words. Word acronyms are written in capital, when they are formed from proper nouns

- WASP $<$ W(hite) A(nglo)-S(axon) P(rotestant)

- $\quad$ SALT $<$ S(trategic) A(rms) L(imitation) T(alks)

- $\quad$ NATO $<$ N(orth) A(tlantic) T(reaty) O(rganization)

- $\quad$ AIDS $<$ a(cquired) i(mmune) d(eficiency) s(yndrome)

- $\quad$ radar $<$ ra(dio) d(etecting) a(nd) r(anging)

- laser < 1(ight) a(mplification) (by) s(timulated) e(mission) (of) r(adiation)

- $\quad$ sonar $<$ so(und) na(vigation) $r$ (anging)

- NASA, National Aeronautics and Space Administration (Brinton \& Brinton, 2010, p. 109)

\subsection{Spelling Acronyms/Initialism}

Initialism, like word acronym, is produced by taking the initial letters of a set words. In contrast, in initialism, the taken letters are not treated as a single word and they are not pronounced as an individual word. Instead, these letters remain on their own and each one is pronounced as a letter. For proper nouns, the letters are written in capitals.

- PR-Public relation

- UN-United Nations

- USA - United States of America

- CD—compact disk (Plag, 2003, p. 127; Brinton \& Brinton, 2010, p. 110)

\subsubsection{Clipping}

Another process for shortening words is known as clipping, in which a new lexeme is formed with the same word class and meaning by dropping a part of a word, usually the beginning or the end. There is a tendency to shorten those words that consist of two or more syllables by clipping, deliberately, one of the syllables. This does not mean that there is no clipping in polysyllabic words. There are some examples of clipping in polysyllabic words, in which the first syllable or the first and the second syllable is retained.

- hyp for hypochondriac

- rep for reputation 
- ult for ultimate

- penult for penultimate

- incog for incognito

- hyper for hypercritic

- extra for extraordinary (Katamba, 1994, pp. 124-125; Brinton \& Brinton, 2010, p. 108)

There are four types of clipping:

2.1.7.1 Fore-clipping: In this type, the beginning is dropped down:

- plane from airplane

- bus from omnibus

- van from caravan

2.1.7.2 Back-clipping: This is the most common type in which the end is dropped down:

- info from information

- rep from representative

- limo from limousine

- bike from bicycle

- lab from laboratory

2.1.7.3 Fore and back- clipping: In this type, the beginning and the end of the word is dropped and a part of the word in the middle is retained:

- fridge from refrigerator

- $\quad$ flu from influenza

2.1.7.4 Complex-Clipping: In this type, a part in a couple words is dropped down at the same time:

- Sitcom from situation comedy

Moreover, there is clipping in compound words, but in this type, only a part of either on the left or the right side of the compound word is dropped and the other side remains as it is.

- cablegram from cable telegram

- $\quad$ op art from optical art

- org-man from organization man (Katamba, 1994, p. 125; Meyer, 2009, p. 181; Brinton \& Brinton, 2010, pp. 108-109)

\subsubsection{Backformation}

In English, in general, words are formed by adding affixes. In contrast, in the process of backformation, a new lexeme is produced as a result of removing a suffix from the base of the word. Thus, in this process, the word is shortened and a new lexeme is formed with a different class and meaning. In the process of backformation, verbs are usually formed from nouns.

- Typewriter (n) - er = typewrite (v)

- Television (n) - sion $=$ televise $(\mathrm{v})$

- $\operatorname{Revision}(\mathrm{n})$ - sion $=$ revise (v)

- $\quad$ Keeper (n) - er = keep (v) (Katamba, 1994, p. 128)

\subsubsection{Blending}

Blending is another process of word formation in which two different parts of two different words are combined and a new lexeme is produced. Thus, a blend involves two processes of word formation: compounding and clipping. Two free morphemes are combined and blended by clipping off the end of the first word and the beginning of the second word.

- $\quad$ Smoke + fog $=\operatorname{smog}$

- Breakfast + lunch $=$ brunch

- $\quad$ Motor + hotel $=$ motel 
- $\quad$ Spanish + English $=$ Spanglish

For words related to information technology, the beginnings of both words are blended.

- Teleprinter + exchange $=$ telex

- $\quad$ Modulator + demodulator $=$ modem (Brinton $\&$ Brinton, 2010, p. 107; Yule, 2010, pp. 55-56)

\subsection{Lexical Enrichment in English by Borrowing Words from Other Languages}

Loaning words is a very common phenomenon and no language is completely free of borrowed words (Jesperson, 1922). It is very normal for languages to borrow words from other languages. To Fromkin et al. (2003), borrowing words is important especially when the giving language adds new words or morphemes to the other language. When languages come into contact, there is a transfer of linguistic items from one language to another due to the borrowing of words (Kachru, 1994). Borrowing words from other languages, in English, is regarded as one of the most important ways by which language is enriched. With the passage of time, English has borrowed many words from other languages.

- Croissant from French

- Dope from Dutch

- Lilac from Persian

- Piano from Italian

- Pretzel from German

- Sofa from Arabic

- Taboo from Tahitian

- Tycoon from Japanese

- Yogurt from Turkish

- Zebra from Bantu (Yule, 2010, p. 54)

On the other side, other languages have borrowed words from English. For instance:

- The word 'suupaa' or 'suupaamaaketto' in Japan comes from the word 'supermarket' in English.

- The word 'taipuraita' in Japan comes from the word 'typewriter' in English

- The word 'klub' in Hungarian comes from the word 'club' in English

- The word 'fubal' in Hungarian comes from the word 'football' in English

- The word 'sport' in Hungarian comes from English

Sometimes, the borrowed words are used with quite different meanings. For example, the English words 'partner' and 'look' are used in German in the phrase 'im partnerlook', which is used to describe two people who are together and are wearing similar clothing. There is no equivalent use of this expression in English (ibid).

There are some borrowed terms in English that are known as 'calque' or 'loan-translation', because there is a direct translation of the elements of a word into the borrowing language. For instance, the French word 'gratt-ciel' is a calque that literally translates as 'skyscraper'. Also, the expression 'moment of truth', in English, is a calque from the Spanish phrase 'el momento de la verdad'. It is possible for a word to be a borrowed word in one language, but a calque from other languages. For instance, the word 'boyifurendo', in Japan, is regarded as borrowing, with sound modification, but it is reviewed as a calque into Chinese as 'male friend' (Yule, 2010, p. 54).

\section{Lexical Enrichment in Kurdish}

\subsection{Lexical Enrichment in Kurdish by Word-Formation}

\subsubsection{Affixation}

The process of affixation in Kurdish, like in English, is the most common way by which a new form is made. Unlike English, affixation in Kurdish language includes circumfixation as another common way, as well, alongside prefixation and suffixation. On the other hand, infixation is less common in both languages.

\subsubsection{Prefixes}

Prefixes, in Kurdish language, may change the class of words. This is different from English in which the class of word is never changed. In the set of below words, the class of words is not changed after the addition of 
prefixes:

$\begin{array}{lll} & \text { Noun } & \underline{\text { noun }} \\ \text { - } & \text { Ser (head) } & \text { hawser (spouse) } \\ \text { - } & \text { Raz (symathy) } & \text { hawraz (having the same sympathy) } \\ & \text { Adjective } & \underline{\text { adjective }} \\ \text { - } & \text { Drust (correct) } & \text { nadrust (incorrect) } \\ - & \text { Pak (loyal) } & \text { napak (disloyal) } \\ & \text { Infinitive } & \underline{\text { infinitive }} \\ - & \text { Kirdin (to do) } & \text { hel'kirdin (to switch on) } \\ -\quad \text { Çûn (to go) } & \text { deçûn (to collapse) } \\ -\quad \text { Alan (to twist) } & \text { lêkaṬan (to tangle) }\end{array}$

But in the following words, the class of the word is changed and a new lexical item comes into the language:

- Hat (verb stem) dahat (noun)

- Naz (noun) benaz (adjective) (Qadîr, 2002, pp. 47-49)

\subsubsection{Suffixes}

In the Kurdish language, like English, some derivational suffixes do not change the class of words, but a new word is formed with the same class but different meaning. For example:

$\begin{array}{lll} & \text { Noun } & \underline{\text { noun (career) }} \\ -\quad \text { Ga (bull) } & \text { gawan (cowboy) } \\ -\quad \text { Mele (swim) } & \text { melewan (swimmer) } \\ -\quad \text { Mis (copper) } & \text { misgir (coppersmith) } \\ -\quad \text { Ça (tea) } & \text { Çaçî (tea sommelier) } \\ \quad \text { Noun } & \text { diminutive noun } \\ -\quad \text { Mêru (ant) } & \text { mêrule (a little ant) } \\ -\quad \text { Goze (vessel) } & \text { gozel'e (a small vessel) } \\ -\quad \text { Das (sickle) } & \text { dasulke (a small sickle) } \\ & \text { Noun } & \text { noun (place) } \\ -\quad \text { Gul' (flower) } & \text { gul'dan (vase) } \\ -\quad \text { lewer (grass) } & \text { leweriga (field of grass) } \\ -\quad \text { Kurd (Kurd) } & \text { Kurdistan } \\ & \text { Adjective } & \text { adjective } \\ -\quad \text { Nerim (soft) } & \text { nermîn (softish) } \\ -\quad \text { Req (hard) } & \text { reqin (hardish) } \\ & \text { Infinitive } & \text { infinitive } \\ -\quad \text { Kirdin (to do) } & \text { kirdinewe (to unlock) } \\ -\quad \text { Xwêndin (to study) } & \text { xwêndinewe (to read) (Abdullah, 2007: 55-62) }\end{array}$

The following suffixes change the class of the words:

\begin{tabular}{|c|c|}
\hline$\underline{\text { Adjective }}$ & $\underline{\text { noun }}$ \\
\hline Şad $+\hat{\imath}$ (cheerful) & şadî (cheerfulness) \\
\hline Ciwan $+\hat{i}$ (beautiful) & ciwanî (beauty) \\
\hline Noun & $\underline{\text { adjective }}$ \\
\hline Mindal'+ane (child) & mindal'ane (childish) \\
\hline Kiç+ane (girl) & kiçane (girlish) \\
\hline
\end{tabular}




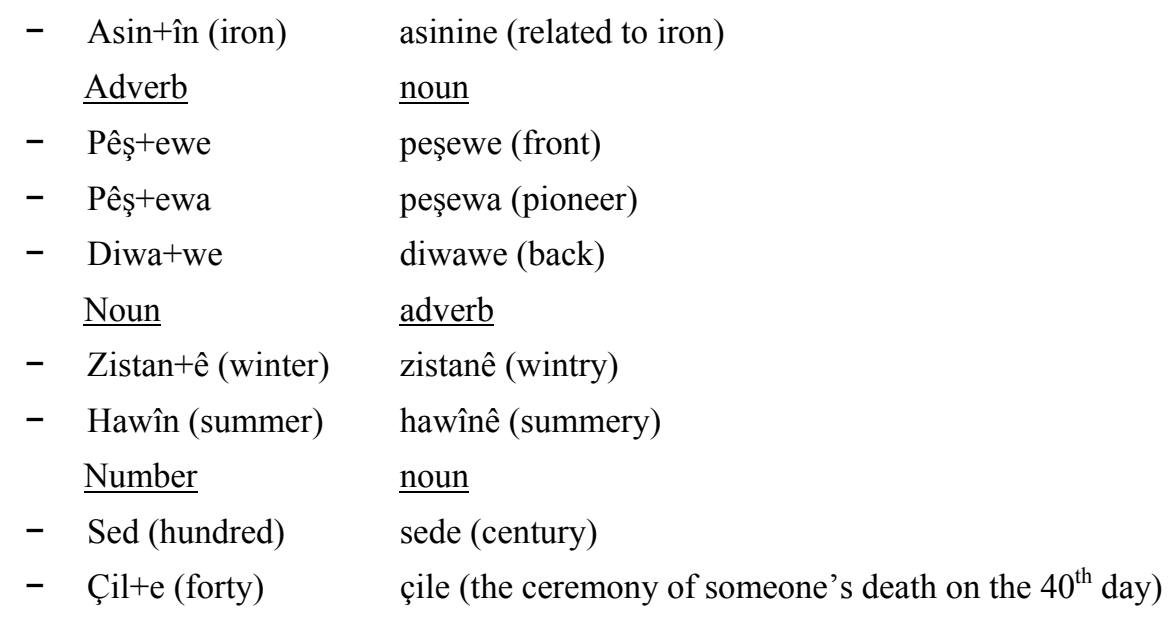

\subsubsection{Circumfix}

To Fetah and Qadîr (2006), the process of circumfixation can be found in Kurdish in which a prefix and a suffix are added to a word at the same time:

- Hel' + kirdin + ewe $\rightarrow$ hel'kirdinewe (rewinding)

- $\quad \mathrm{Da}+$ hênan + ewe $\rightarrow$ dahênanewe (curving)

\subsubsection{Conversion}

Comparing Kurdish to English, conversion is less common in Kurdish language. For example, the word 'ciwan' is used as an adjective in the first sentence, which means 'beautiful', but as a noun in the second sentence, which refers to the name of a girl whose name is Ciwan.

- Mindalêkî ciwan hat. (a beautiful child came)

- Ciwan be pê hat. (Ciwan came on foot) (Fetah \& Qadîr, 2006, pp. 29-31)

\subsubsection{Compounding}

Compounding is a common way in both Kurdish and English. Between the two words, conjunctions are used to combine them:

- Ganim + co $=\operatorname{ganim} \underline{\text { û }}$ co (wheat and barley)

- Gul' + bax $=$ gul'ebax (rose)

- Kêw + reş $=$ kêwereş (black mountain)

The whole word may be repeated, like words related to baby talk:

- Baba (dad)

- Mama (uncle)

- Dada (sister)

Or a part of a word may be repeated for the sake of harmony of tone (rhyming reduplication and ablaut reduplication) and the conjunction ' $u$ ' (and) is used between the two parts:

- $\quad$ Befir (ice) $+u+$ mefir $=$ Befirumefir

- Gêj (idiot) $+\mathrm{u}+$ hêj $=$ Gêjuhêj

- $\quad$ Dar (tree) $+\mathrm{u}+$ bar $=$ Darubar

- Haj (noise) $+u+$ huj = hajuhuj (Besîr, 1978, p. 70)

\subsubsection{Shortening}

Shortening is one of the common ways in which we are shortening a form of a word or two words or a set of words and we are forming a new one for the sake of economy of language.

\subsubsection{Acronym}

Comparing acronym to the other processes of word formation it is less common. In Kurdish, like in English, both words acronym and spelling acronym can be found: 
- YNK from Yekêtî Nîş̧îmanî Kurdistan (YNK is a word acronym)

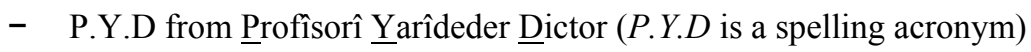

\subsubsection{Clipping}

The process of clipping, in Kurdish, is different from English. In Kurdish language, there are two cases of clipping:

3.1.4.2.1 As a result of compounding, sometimes, there is an omission of a sound between the final part of the first word and the initial part of the second word. This process is somehow similar to elision in phonology that is found in the spoken language, but here it can be found in both spoken and written:

- $\mathrm{Ga}($ bull $)+\operatorname{asin}($ iron $)=$ gasin (plough) ('a' is omitted)

- Masit (yogurt) + âw (water) = mastaw (drinking milk) (' $\mathrm{i}$ ' is omitted and 'â' is changed to 'a')

3.1.4.2.2 As a result of compounding, there is clipping in both words. Clipping usually happens at the end of the first word and at the beginning of the second word:

- $\quad$ Rojname + govar $=$ rovar (newspaper and journal)

- Xûrma + mêwij = xûrmij (sate and raisin) (Besîr, 1978, p. 70; Dizey, 2013, p. 89)

\subsection{Borrowing}

Borrowing, in Kurdish, is very common. Kurdish has borrowed many words from different languages, especially from English. It is a natural phenomenon that the users of the Kurdish language loan words from other languages unconsciously while interacting with other people. In general, the main reason for loaning is the need to acquire new vocabulary or lexical items for new places, things and concepts. More specifically, there are some crucial reasons telling us why borrowing is very common in Kurdish compared to other languages, for example:

1) Kurdish borrowed many words from Arabic because we, as Kurdish people, live in Iraqi Kurdistan and the formal languages in Iraq are Arabic and Kurdish. This case is related to politics. Another reason for borrowing many words from Arabic is related to religion. Most Kurdish people are Muslims and The Holy Quran was written in Arabic. This has a great impact on the Kurdish language:

$$
\begin{array}{ll}
\text { - } & \text { Kirsî (in Arabic) } \rightarrow \text { kursî (chair) (in Kurdish) } \\
\text { - } & \text { el seyare (in Arabic) } \rightarrow \text { seyare (car) (in Kurdish) } \\
\text { - } & \text { Allah (in Arabic) } \rightarrow \text { Ela (God) (in Kurdish) }
\end{array}
$$

2) English is a global language. It is used as a first language or a second language in countries settled by the English. For example, in India, English is used as the second language. Also, English, as a foreign language, is used around the globe for business, science, technology, and commerce. Moreover, it is the lingua franca of the internet and this has a profound effect. Thus, English language has power over Kurdish and other languages.

- Computer (in English) $\rightarrow$ kompîwter (in Kurdish)

- Internet (in English) $\rightarrow$ înternêt (in Kurdish)

Sometimes, there is a change of the borrowed word to fit the phonological system of the borrowing language:

- $\quad$ Surprise (in English) $\rightarrow$ suprayiz (in Kurdish)

- Final (in English) $\rightarrow$ fînal' (in Kurdish)

- Sponsor (in English) $\rightarrow$ siponser (in Kurdish) (Fetah, 1984, p. 104; Abdullah, 2007, p. 129)

The words which are known as calque can be found in Kurdish as well, especially the ones borrowed from Arabic. For example:

- Al-bab al-thanî (from Arabic) $\rightarrow$ dergay diwem (the second door) (in kurdish)

- Al-bina al-fewqî (from Arabic) $\rightarrow$ sexan (triadic) (in Kurdish)

- Al-axrac al-temthîlî (from Arabic) $\rightarrow$ derhênan (a film director) (in Kurdish) (Besîr, 1978, pp. 93 94)

3) Loaning existing words from another language is easier than creating ones.

\section{Conclusions}

The present study covers some similar and dissimilar points between English and Kurdish concerning the methods and the ways of lexical enrichment. The study shows that, in both languages, some ways are more 
common than the other ways of lexical enrichment and vice versa. For example, affixation, compounding and borrowing words from other languages are more common, active and productive ways than the other ways of lexical enrichment in both languages. On the other hand, acronyms, clipping and blending can be found in English and Kurdish but they are less common than the other ways and they are not very productive to enrich language. Also, Shortening, as one of the ways by which new lexical items are made, is used in both languages for the purpose of economy of language, to save time and effort. English, as compared to Kurdish, has more processes and ways of lexical enrichment than Kurdish. In contrast, Kurdish has borrowed far more words than English from other languages, but the process of loaning words is asymmetric, going from English to Kurdish language. Moreover, retronyms, coinage and back formation exist only in English but they are not very productive. There are clipping and blending in Kurdish but they are very rare. Conversion, in English, is more pervasive than it is in Kurdish. In addition to having suffixes and prefixes in English and Kurdish, there are circumfixes (prefix + suffix) in Kurdish language. For instance

- webîrhênanewe (to remind) (a prefix and a suffix are added to the word at the same time)

\section{References}

Abdullah, R. N. (2007). Kurdish dictionary of language and terminology (1st ed.). Sulêymanî: Çwar Çra Press.

Besîr, K. H. (1978). Terminology. Hewlêr. Salahaddin University Press.

Booij, G. (2007). The Grammar of Words: An Introduction to Linguistic Morphology (2nd ed.). Oxford. Oxford University Press. https://doi.org/10.1093/acprof:oso/9780199226245.001.0001

Brinton, L. J., \& Brinton, D. M. (2010). The Linguistic Structure of Modern English. Amsterdam/Philadelphia: John Benjamins Publishing Company. https://doi.org/10.1075/z.156

Denham, K., \& Lobeck, A. (2013). Linguistics for Everyone: An Introduction (2nd ed.). USA: Wadsworth.

Dizey, A. M. (2013). Kurdish morphology (1st ed.). Hewlêr: Awêr Press.

Fetah, M. M. (1984). Verbs and their classification according to derivation. Baghdad: Roşinbîrî Nwê

Fetah, M. M., \& Qadir, S. R.. (2006). Some aspects of Kurdish morphology. Sulêymanî: R̂u Press.

Fromkin, V., Rodman, R., \& Hymas, N. (2003). An Introduction to Language (7th ed.). USA: Thomson.

Haspelmath, M., \& Sims, A. D. (2010). Understanding Morphology (2nd ed.). UK: Hodder Education.

Jesperson, O. (1922). Language: Its Nature, Development and Origin. New York: Henry Holt.

Kachru, B. B. (1994). The speaking tree: A medium of plural canons. In Georgetown Round Table in Languages and Linguistics (GURT). Washington, D.C.: Georgetown University Press.

Katamba, F. (1994). English Words. London and New York: Routledge.

Katamba, F., \& Stoneham, J. (2006). Morphology (2nd ed.). New York: Palgrave Macmillan. https://doi.org/10.1007/978-1-137-11131-9

Lieber, R. (2012). Introducing Morphology (3rd ed.). Cambridge: Cambridge University Press Inc.

Meyer, C. F. (2009). Introducing English Linguistics. Cambridge: Cambridge University press. https://doi.org/10.1017/CBO9780511757822

Plag. I. (2003). Word-Formation in English. Cambridge: Cambridge University Press. https://doi.org/10.1017/CBO9780511841323

Qadir, Ș. H. (2002). Bound morphemes, lexical and functional and their functions in dialect of Goran. Sulêymanî: Sulêymanî University.

Yule, G. (2010). The Study of Language. Cambridge: Cambridge University Press.

\section{Appendix A}

\section{List of Kurdish Consonants sounds}

$\begin{array}{llll}\text { /p/ } & \text { pir } & \text { /pi:r/ } & \text { 'old' } \\ \text { /b/ } & \text { bîr } & \text { /bir/ } & \text { 'well' } \\ \text { /t/ } & \text { tor } & \text { /toR/ } & \text { 'net' }\end{array}$




\begin{tabular}{|c|c|c|c|}
\hline$/ \mathrm{d} /$ & dest & /dəst/ & 'hand' \\
\hline$/ \mathrm{k} /$ & kûr & $/ \mathrm{ku}: \mathrm{R} /$ & 'hunched' \\
\hline$/ g /$ & gồ & /go:R/ & 'grave' \\
\hline$/ \mathrm{q} /$ & qûि & /quR/ & 'mud' \\
\hline /P/ & ew & /Pәw/ & 'he, she, or it' \\
\hline$/ \mathrm{f} /$ & befir & /bəfr / & 'snow' \\
\hline$/ \mathrm{v} /$ & mirov & $/ \mathrm{mrvv} /$ & 'human' \\
\hline$/ \mathrm{s} /$ & sed & /səd/ & 'hundred' \\
\hline $\mid \mathrm{z} /$ & zer̂ & /zeR/ & 'gold' \\
\hline $\mid s /$ & şew & / $\mathrm{J} \partial \mathrm{w} /$ & 'night' \\
\hline $\mid 3 /$ & jûr & /zu:r/ & 'room' \\
\hline$/ \mathrm{x} /$ & xiwê & /xwe/ & 'salt' \\
\hline$/ \mathrm{y} /$ & $\ddot{\mathrm{x} e m}$ & /yəm/ & 'grief' \\
\hline$/ \mathrm{h} /$ & heb & /həb/ & 'pill' \\
\hline$/ \mathrm{S} /$ & 'ereb & /ৎərəb/ & 'Arab' \\
\hline$/ \mathrm{h} /$ & hest & /həst/ & 'feeling' \\
\hline$|\mathfrak{y}|$ & Çep & /Çəp/ & 'left' \\
\hline$/ 1 /$ & lêw & /lew/ & ‘lip’ \\
\hline$/ \mathrm{d} /$ & cor & $/ \mathrm{cor} /$ & 'type' \\
\hline$/ 1 /$ & hêl & /het/ & 'line' \\
\hline$/ \mathrm{m} /$ & mired & $/ \mathrm{mIrd} /$ & 'died' \\
\hline$/ \mathrm{n} /$ & nêr & /ner/ & 'male' \\
\hline$/ \mathrm{r} /$ & pêrê & /pere/ & 'the day before yesterday' \\
\hline$/ \mathrm{R} /$ & kur̂ & $/ \mathrm{kvR} /$ & 'boy’ \\
\hline$/ \mathrm{w} /$ & wêne & /wenə/ & 'picture' \\
\hline$/ \mathrm{j} /$ & yek & $/ \mathrm{j} \Lambda \mathrm{k} /$ & 'one’ \\
\hline
\end{tabular}

\section{Appendix B}

\section{List of Kurdish Vowel sounds}

\begin{tabular}{|c|c|c|}
\hline /i:/ sîr & /si:r/ & 'garlic' \\
\hline /i/ xiwardî & /xwa:rdi/ & 'he ate' \\
\hline mirdin & /mirdin / & 'death' \\
\hline /e/ mê & $/ \mathrm{me} /$ & 'female' \\
\hline$/ a / d e$ & /da/ & 'ten' \\
\hline /a:/ dar & /da:r/ & 'wood' \\
\hline$/ \mho /$ gund & /gond/ & 'village' \\
\hline u:/ dûr & /du:r/ & 'far' \\
\hline$/ \mathrm{p} /$ bon & /bpn/ & 'perfume' \\
\hline
\end{tabular}

\section{Copyrights}

Copyright for this article is retained by the author, with first publication rights granted to the journal.

This is an open-access article distributed under the terms and conditions of the Creative Commons Attribution license (http://creativecommons.org/licenses/by/4.0/). 